\title{
Mobility of Pratylenchus coffeae in segmented soil columns submitted to water flows and plant stimuli
}

\section{Mobilidade de Pratylenchus coffeae no solo em colunas segmentadas submetidas a fluxos de água e estímulos vegetais}

\author{
Bruno Eduardo Alves Barros ${ }^{1}$; Elvira Maria Regis Pedrosa ${ }^{2 *}$; Ênio Farias de França \\ e Silva ${ }^{2}$; Mario Monteiro Rolim²; Patrícia Ângelo de Barros ${ }^{3}$
}

\begin{abstract}
The root-lesion nematode Pratylenchus spp. causes a high-severity disease, promoting high economic losses in various crops of agricultural importance. The nematode control is difficult, especially after introduction into the area. Studies on the migration of this parasite in the soil are scarce. However, understanding nematode behavior in the soil is fundamental to increase the efficiency of management practices, especially in irrigated agriculture. This study aimed to evaluate the influence of water flow and plant stimulus on Pratylenchus coffeae mobility in segmented soil columns. The columns were segmented into 11 rings of $1 \mathrm{~cm}$ long filled with washed sand, one of the ends exposed to a bait, and submitted to flows of $0,3,7 \mathrm{~cm}^{3} / \mathrm{min}$ of water. Baits for nematode attraction and repelling consisted of sectioned tubers of yam (Dioscorea cayennensis) and cut leaves of neem (Azadirachta indica), respectively, and the absence of baits as the control. Nematodes were injected into the central segment of the column, and migration and presence in water leaching were determined five days after soil infestation. Mobility of $P$. coffeae varied with water flow and bait type. In the absence of water flow, nematodes migrated in the opposite direction to the neem baits, but migration was well distributed in the presence of yam baits, with specimens present in all column segments. The nematode had significantly higher resistance to water flow of $3 \mathrm{~cm}^{3} / \mathrm{min}$ in the presence of yam baits. No nematodes were found in the water leached at flows of 3 and $7 \mathrm{~cm}^{3} / \mathrm{min}$ in the absence of bait.
\end{abstract}

Key words: Azadirachta indica. Dioscorea cayennensis. Lesion nematode. Soil dispersion.

\section{Resumo}

O nematoide das lesões radiculares Pratylenchus spp. causa doença de alta severidade promovendo elevadas perdas econômicas em inúmeras culturas de importância agrícola. O controle é difícil, principalmente depois de sua introdução na área. Estudos sobre a migração desse parasito no solo são escassos. No entanto, entender o comportamento do nematoide no solo é fundamental para aumentar a eficiência das práticas de manejo, especialmente em agricultura irrigada. O objetivo do estudo foi avaliar a influência do fluxo de água e do estímulo vegetal na mobilidade de Pratylenchus coffeae em colunas de solo. As colunas foram segmentadas em 11 anéis de $1 \mathrm{~cm}$ de comprimento, preenchidas com areia lavada, tendo uma das extremidades exposta à isca e submetida a fluxos de $0,3,7 \mathrm{~cm}^{3} / \mathrm{min}$ de água. As iscas para atração e afastamento do nematoide consistiram de túberas seccionadas de inhame

\footnotetext{
1 Discente, Curso de Mestrado, Programa de Pós-Graduação em Engenharia Agrícola, Universidade Federal Rural de Pernambuco, UFRPE, Recife, PE, Brasil. E-mail: beduardo@outlook.com

2 Profs. Drs., Departamento de Engenharia Agrícola, UFRPE, Recife, PE, Brasil. E-mail: elvira.pedrosa@ufrpe.br; enio.fsilva@ ufrpe.br; mario.rolim@ufrpe.br

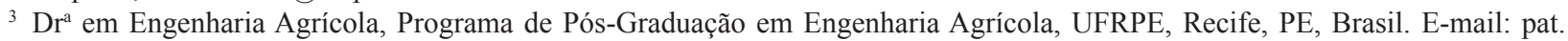
angell@hotmail.com

* Author for correspondence
} 
(Dioscorea cayennensis) e folhas picotadas de nim (Azadirachta indica), respectivamente, e a ausência de iscas como testemunha. Os nematoides foram injetados no segmento central da coluna e a migração e lixiviação determinadas cinco dias após infestação do solo. A mobilidade de $P$. coffeae variou com fluxo de água e tipo de isca. $\mathrm{Na}$ ausência de fluxo de água os nematoides migraram em sentido contrário às iscas de nim, mas a migração foi bem distribuída na presença de iscas de inhame, com espécimes presentes em todos os segmentos da coluna. Quando aplicado fluxo de $3 \mathrm{~cm}^{3} / \mathrm{min}$ de água, P.coffeae ofereceu significativamente maior resistência ao fluxo na presença de iscas de inhame. Os nematoides não foram lixiviados nos fluxos de 3 e $7 \mathrm{~cm}^{3} / \mathrm{min}$ de água na ausência de isca.

Palavras-chave: Azadirachta indica. Dioscorea cayennensis. Dispersão no solo. Nematoide das lesões radiculares.

\section{Introduction}

The root-lesion nematodes Pratylenchus spp. are migratory endoparasites, soil inhabitants, considered of great agricultural importance due to the damage they cause to crops and difficult control (TALWANA et al., 2016). Losses caused by this nematode around the world have been estimated at 10 to $80 \%$, depending on several factors (FERRAZ; BROWN, 2016).

Seventy Pratylenchus species have already been registered in the world (MAJD TAHERI et al., 2013). Due to the widespread and high incidence, the root-lesion nematode can be found in all agricultural regions (TALWANA et al., 2016). In Brazil, considering the economic losses, damages, geographical distribution, and number of hosts, the most important nematode species are Pratylenchus brachyurus (GODFREY, 1929) Filipjev \& Schuurmans Stekhoven, 1941, P. zeae Graham, 1951, and P. coffeae Goodey, 1951 (GOULART, 2008; ARAÚJO FILHO et al., 2014). Pratylenchus coffeae was first reported in the Northeast of Brazil by Moura and Monteiro (1995) on yam (Dioscorea cayennensis Lam.) causing symptoms similar to those of the dry rot disease.

After hatching, P. coffeae moves in the soil or inside the roots of host plants during the other stages of the life cycle due to its migrating habit. In the soil, the nematode moves through water films that cover soil particles toward the spaces formed between particles (pores), whose size depends mainly on soil texture (BARROS et al., 2016).

Soil texture is one of the main factors influencing P. coffeae distribution (FERRAZ; BROWN,
2016). Sandy and medium textured soils favor this nematode. When combined with adequate moisture, they can survive in moist soil for several months even in the absence of host (DIAS et al., 2008).

Soil moisture is an important factor for the plantparasitic nematodes development and parasitism, exerting a high influence on nematofauna dynamics. Therefore, any change in soil water content can affect nematode mobility and population density (GRIFFITHS; CAUL, 1993).

Nematode mobility is an important factor for the degree of infection in the host. In the soil, nematodes have the capacity to move for a distance of no more than 1 to $2 \mathrm{~m}$ from the rhizosphere of the plant they infect, although many agricultural operations, especially those involving traffic of machinery and vehicles, favor the more pronounced nematode dispersion in the field (CASTILLO; VOVLAS, 2007).

Nematode dissemination by water is an important contamination process (BURR; ROBINSON, 2004). According to Du Charme (1955), water movement through the soil favors the passage of nematodes. The trend in soil water flow is influenced by precipitation, evaporation, and transpiration, among other variables, resulting in that soil water is always in motion, therefore soil nematode movement must be affected by soil water flows (FUJIMOTO et al., 2010).

The host plant is another important factor that affects nematode mobility in the soil. One of the initial phases of the parasitic relationship with the host plant is the attraction that it exerts on the nematode due to the presence of organic compounds produced and released by roots (WILLIAMSON; 
KUMAR, 2006; HOLBEIN et al., 2016). However, some plants have an antagonistic effect on plantparasitic nematodes, such as neem and several species of crotalaria (FERRAZ; FREITAS, 2004; FERRAZ et al., 2010), which can produce toxic substances, repelling or inhibiting nematode movement (OKA, 2010; PINHEIRO, 2016).

This study aimed to evaluate the influence of water flow and the stimulus of plant baits made from yam, an attractive and good host plant, and neem (Azadirachta indica A. Juss), an antagonistic plant, on the mobility of $P$. coffeae in horizontal segmented soil columns.

\section{Material and Methods}

\section{Obtaining P. coffeae populations}

Pratylenchus coffeae populations were obtained from nematode-infected yam tubers marketed at the Center of Supply and Logistics of Pernambuco - CEASA, Recife, PE. Yam tubers were submitted to nematode extraction using the Baermann funnel technique (BAERMANN, 1917). Yam peels were placed on a sieve lined with tissues resting on a container, where water was added until it partially covered the bottom of the sieve containing the peels. Nematodes moved from tubers toward water due to the positive hydrotropism, decanting in the container bottom by the action of gravity. After 24 hours of standing, water containing juveniles and adults of $P$. coffeae was drained onto a 500-mesh sieve. Then, the suspension containing nematodes was transferred to a Becker and placed in a refrigerator for subsequent counting using a Peter chamber under a microscope.

\section{Preparation of soil columns}

Columns were made of acrylic resin with $2.2 \mathrm{~cm}$ inner diameter, $3 \mathrm{~cm}^{2}$ cross section, $11 \mathrm{~cm}$ long, and $41.8 \mathrm{~cm}^{3}$ volume, being segmented into 11 rings of 1 $\mathrm{cm}$ in length and filled with washed sand depending on the density $\left(1.34 \mathrm{~g} \mathrm{~cm}^{-3}\right)$ for maximum soil water retention, as in Francelino et al. (2017). Before filling the columns, the washed sand was autoclaved at $120^{\circ} \mathrm{C}$ and pressure of one atmosphere for 2 hours. Subsequently, sand was oven dried at $65{ }^{\circ} \mathrm{C}$ for 24 hours, and particle size and density, soil density, and total porosity were analyzed (Table 1). After filling, the columns were submitted to saturation with sterile water using a serum dispenser. After 24 hours, excess water was drained to reach the field capacity and present a water film between sand particles, allowing nematode mobility (Figure 1).

Table 1. Physical characteristics of washed sand.

\begin{tabular}{cc}
\hline Physical characteristics & \\
\hline Particles Density $\left(\mathrm{g} \mathrm{cm}^{-3}\right)$ & 2.65 \\
Soil Density $\left(\mathrm{g} \mathrm{cm}^{-3}\right)$ & 1.34 \\
Porosity $(\%)$ & 49 \\
\hline
\end{tabular}

Extra rings of $1 \mathrm{~cm}$ long were added at the ends of columns separated by a 325 mesh for bait packing.

A peristaltic pump was used for the studies with water flow, and screens were inserted at the ends of columns, allowing the uniform water flow dispersion along the column and preventing sand from escaping through the exit point (Figure 2).

\section{Conduction of experiments}

The studies were carried out in the Laboratory of plant-parasitic nematodes of the Federal Rural University of Pernambuco. Three experiments were conducted, one without and two with water flow. 
Figure 1. Scheme of the experimental device used to evaluate the movement of Pratylenchus coffeae in non-saturated columns filled with washed sand.
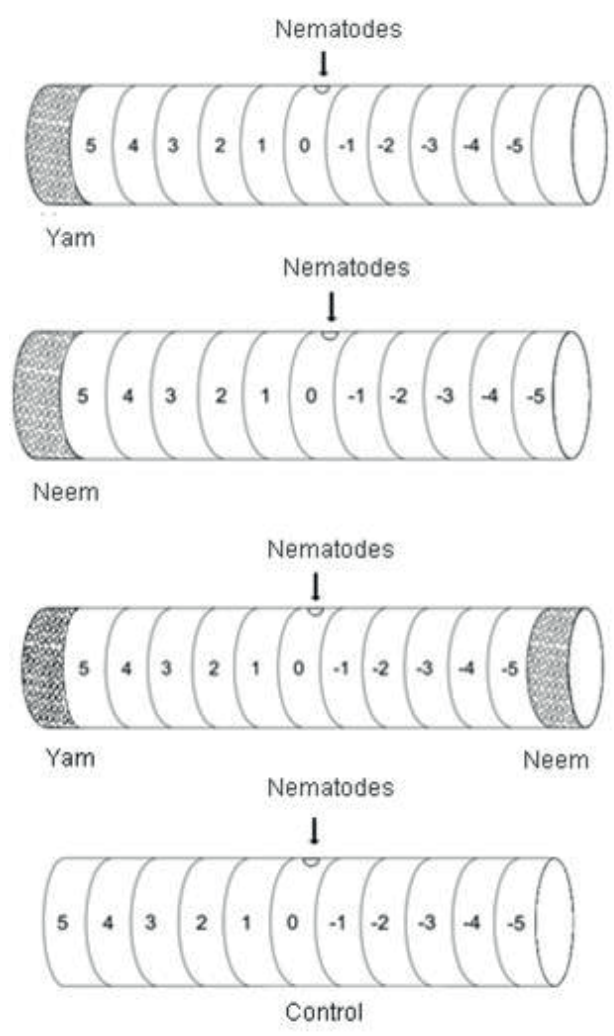

Figure 2. Scheme of the experimental device used to evaluate the movement of Pratylenchus coffeae in columns of washed sand submitted to water flow.

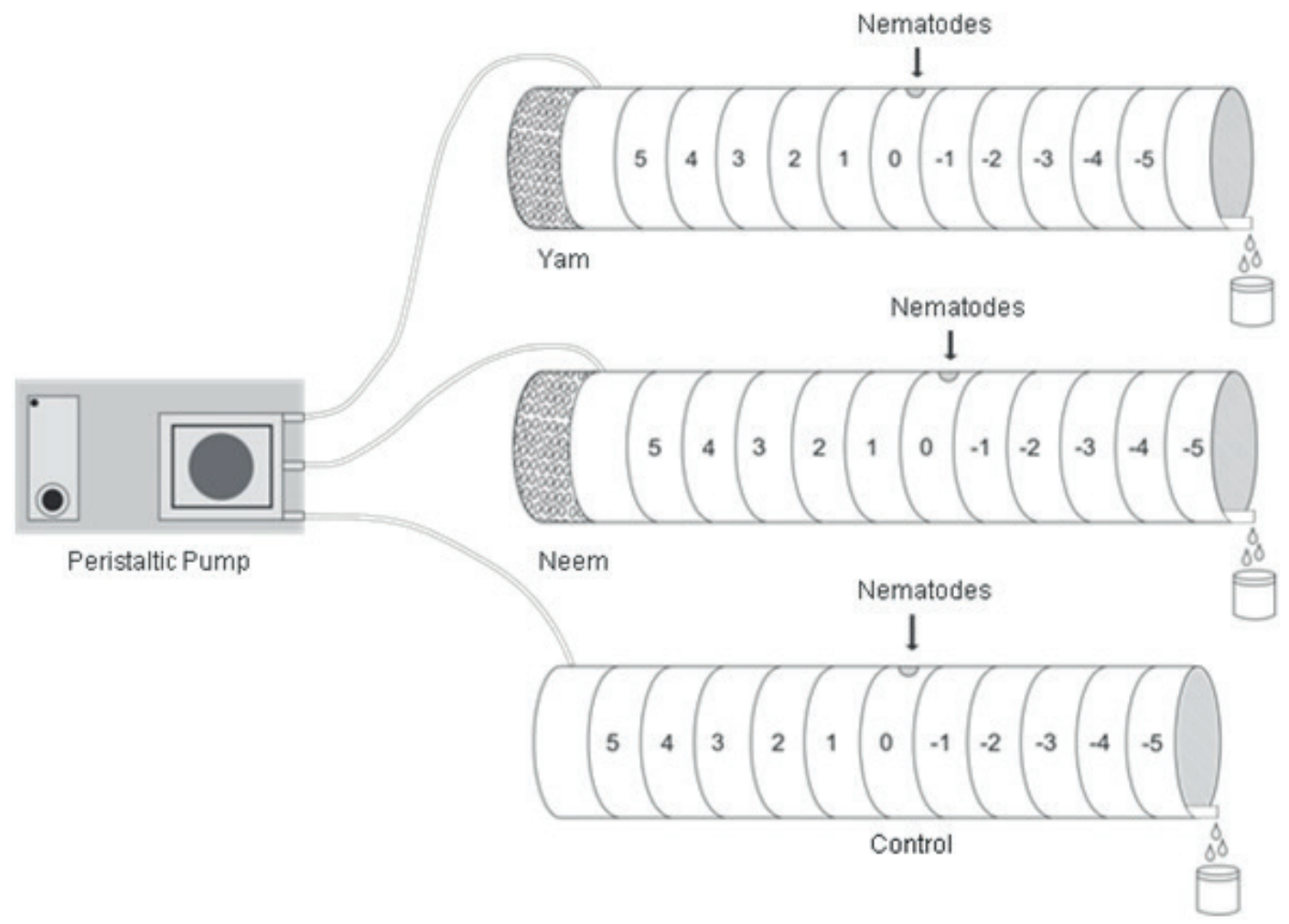


Baits consisting of sectioned yam tubers and cut leaves of neem were used for attraction and repelling of the nematode, respectively. Columns without the presence of baits were used as the control.

The experiment without water flow (first experiment) was conducted in a completely randomized design with four treatments and four replications. Treatments were structured according to the arrangement of baits at the horizontal ends of the column: yam bait + no bait, neem bait + no bait, yam bait + neem bait, and no baits (Figure 1). Columns were held horizontally, and nematodes injected into the central segment. Migration was determined at five days after soil infestation. For evaluation, the injection point $(0 \mathrm{~cm})$ was taken as the starting point, and positive values were assigned to the segments from the injection point to indicate nematode movement towards the baits, while negative values indicated the movement in the opposite direction to the baits; when two baits were used, positive values were taken towards yam (Figure 1).

Both water flow experiments were conducted in a completely randomized design with three treatments and four replications. Treatments were structured according to the arrangement of baits at the horizontal ends of the column: yam bait + no bait, neem bait + no bait, and no baits. Nematodes were injected into the central segment of the column and the end exposed to the bait was submitted to water flows of 3 (second experiment) or 7 (third experiment) $\mathrm{cm}^{3} / \mathrm{min}$. A plastic tube connected to the exit point led the flow of water to collection flasks (FUJIMOTO et al., 2009) for counting the leached nematodes using a Peter chamber under a microscope. Meshes inserted at the ends of columns assisted in preventing sand from escaping from the exit point and allowed uniform water flow dispersion along the column. Migration and drained nematode were determined at five days after soil infestation, using the evaluation adopted in the experiment without water flow (Figure 2).
The ambient temperature and inside the column, monitored throughout the experimental period with an OSENT $\mathrm{HOBO}^{\circledR}$ data logger, remained at $25.5 \pm 1.5{ }^{\circ} \mathrm{C}$. Moisture loss of the saturated soil during the study period, determined by the standard greenhouse method (EMBRAPA, 2011), was 0.01 and $0.0048 \mathrm{~g}$ of water in the evaluations without and with the flow, respectively.

\section{Statistical analysis}

The experiments were analyzed separately by applying the chi-square test $\left(X^{2}\right)$ to compare nematode distribution frequencies between treatments and according to the direction taken as a function of the used bait.

\section{Results and Discussion}

The movement of $P$. coffeae was significantly affected by the inserted baits in the experiment without water flow (Table 2).

Nematode mobility was well distributed in the presence of sectioned yam tubers, presenting specimens at all distances in the soil column; 16.3\% of the nematodes injected into the column were able to move $5 \mathrm{~cm}$ from the injection point $(0 \mathrm{~cm})$ towards the segment closest to the yam bait (Figure $3 \mathrm{~A})$. However, the highest nematode concentrations of 20.5 and $24.3 \%$ occurred at positions +3 (towards yam bait) and $-3 \mathrm{~cm}$ (opposite to the bait), respectively. This result suggests that the bait was not efficient at attracting the nematode, at least during the experimental period. When studying the mobility of juveniles of Meloidogyne incognita (Kofoid and White) Chitwood 1949 in sand columns without water flow and without bait use, Fujimoto et al. (2010) observed that nematode population was completely distributed to both sides of the column on the seventh day after injection, with a similar number of individuals at each column section. 
Table 2. Chi-square values and significance of Pratylenchus coffeae distribution in the sectioned columns with different baits (treatments) and direction (positive and negative) of nematode movement in soil columns.

\begin{tabular}{lc}
\hline Variable & $X^{2}$ \\
\hline Treatments & Experiment without water flow \\
Direction in yam & $129.18^{* *}$ \\
Direction in neem & $31.83^{* *}$ \\
Direction in neem + yam & $55.23^{* *}$ \\
Direction without bait & $11.89^{*}$ \\
\hline & $18.24^{* *}$ \\
\hline Treatments & Experiment with flow of $3 \mathrm{~cm}^{3} / \mathrm{min}$ of water \\
Direction in yam & $108.37^{* *}$ \\
Direction in neem & $41.43^{* *}$ \\
Direction without bait & $29.42^{* *}$ \\
\hline & $10.90^{* *}$ \\
\hline Treatments & $86.83^{* *}$ \\
Direction in yam & $47.29^{* *}$ \\
Direction in neem & $19.23^{* *}$ \\
Direction without bait & $24.79^{* *}$ \\
\hline
\end{tabular}

* significant at $5 \%$ probability

** significant at $1 \%$ probability.

Figure 3. Distribution of Pratylenchus coffeae according to direction and type of bait in columns with sand washed without water flow five days after the nematode injection. Sectioned column with baits of yams (A); Sectioned column with baits of neem leaves (B); Sectioned column with baits of yam and neem leaves (C); Sectioned column with no baits (D). Nematode distribution from the injection point differed between the four bait conditions by the Chi-square test $(P \leq 0.01)$.
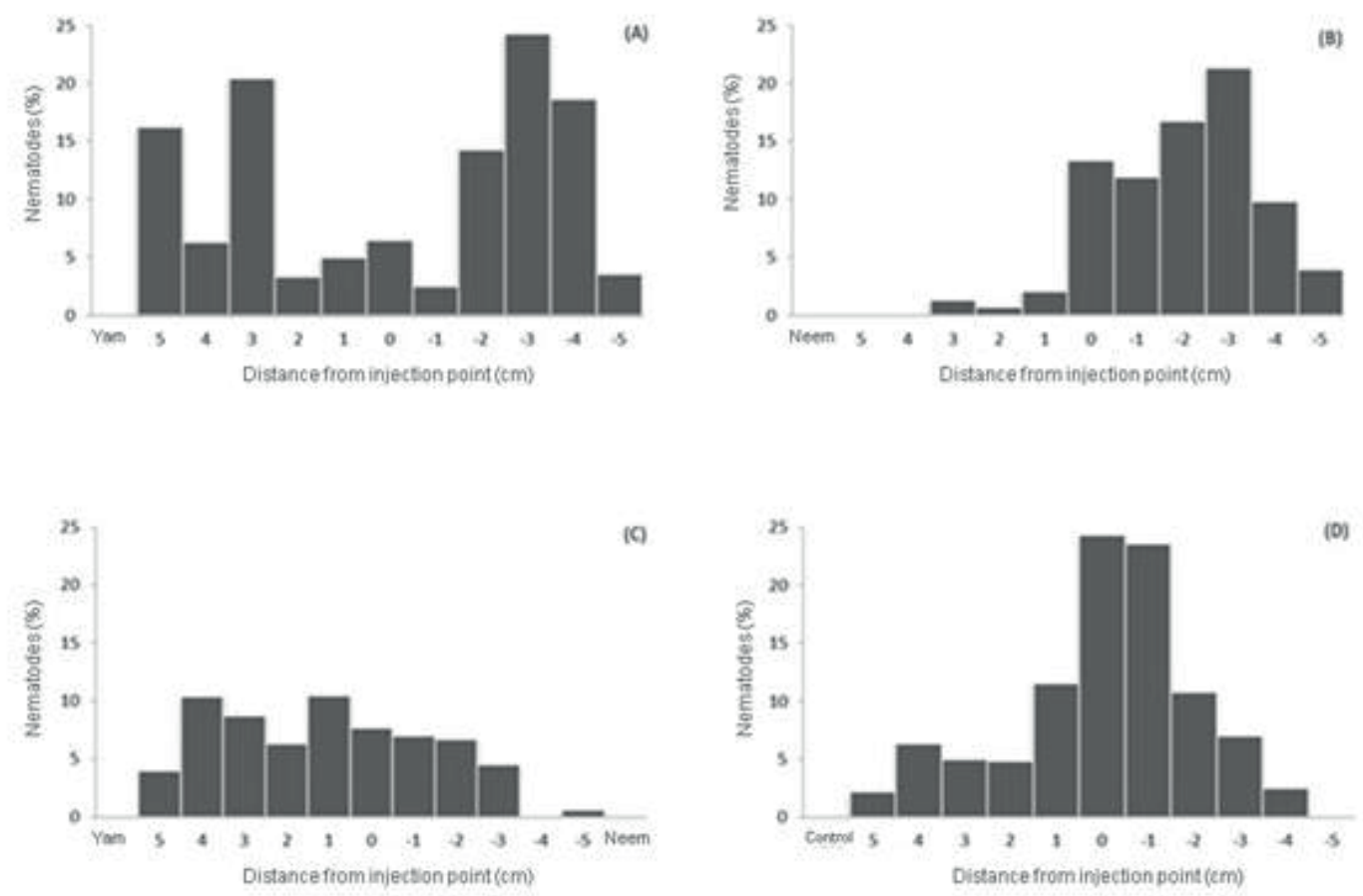
Neem leaves affected significantly (Table 2) nematode movement, which migrated in the opposite direction to the bait. The highest $P$. coffeae concentrations, with values of 21.3 and $16.7 \%$, were observed at positions -3 and $-2 \mathrm{~cm}$, respectively (Figure 3B), corroborating the repellent action of neem leaves to the nematodes (SCHUMUTTERER, 1990). Different parts of neem are known to contain more than 40 active ingredients belonging to the groups of diterpenoids, triterpenoids, limonoids, and flavonoids (HOSSAIN et al., 2013). Several active ingredients have already been isolated from neem oil, such as nimbin ( $0.1 \%$ of the oil composition), nimbinin $(0.01 \%)$ and nimbidin $(1.1 \%)$ (NEVES et al., 2003), and the nematicide effect of neem extract to $P$. brachyurus has been verified in the field (EGUNJOBI; AFOLAMI, 1976). Exudates of neem roots were toxic to the ectoparasites Hoplolaimus sp. Daday, Helicotylenchus sp. Steiner, Rotylenchulus sp. Filipjev, and Tylenchus sp. Bastian, as well as inhibited hatching of juveniles of $M$. incognita (SIDDIQUI; ALAM, 1989).

The column with yam and neem baits at each end confirmed once again the repellent effect of neem leaves, directing significantly (Table 2) nematode migration to positions contrary to leaves and towards yam tubers, with a value of $10.4 \%$ at position $+4 \mathrm{~cm}$ (Figure 3C). This nematode has been affecting the yam crop, with a high prevalence in the Pernambuco State (MOURA, 2002).
In the treatment without baits used as a control, the migrating habit of P. coffeae promoted a welldistributed movement throughout the column, in which nematodes moved in both directions and reached its ends (Figure 3D). However, a significant difference (Table 2) was observed in the distribution, with the highest nematode concentrations remaining close to the injection positions, with values of 23.6 and $24.3 \%$ at positions -1 and $0 \mathrm{~cm}$, respectively, showing, in general, no stimulus. Francilino et al. (2017) observed the same situation when evaluating $P$. coffeae movement in a soil column in which most specimens were found near the injection point. In this case, the nematode movement was slow because there was no stimulus (positive or negative).

No nematode was found in the drainage water with constant water flow application of $3 \mathrm{~cm}^{3} /$ min through the column with yam bait (Table 3 ), indicating the specimens remained within the column. However, Francilino et al. (2017) observed that a flow rate of $5 \mathrm{~cm}^{3} / \mathrm{min}$ was sufficient to drain $P$. coffeae specimens using yam tubers as bait. In spite of the significant difference in nematode distribution in the column (Table 2), the population was distributed in all column sections even in the last section $(-5 \mathrm{~cm})$, which had $2.4 \%$ of the inoculated nematodes, suggesting that the flow dragged the nematodes to the opposite position to the sectioned yam bait. However, a high number of specimens were found at position $+5 \mathrm{~cm}(72.3 \%)$, which is close to the bait, evidencing a resistance to flow (Figure 4A).

Table 3. Number of Pratylenchus coffeae specimens collected from drainage water at end of column.

\begin{tabular}{lcc}
\hline & \multicolumn{3}{c}{ Number of Nematodes } \\
\cline { 2 - 4 } Baits & $3 \mathrm{~cm}^{3} / \mathrm{min}$ & Water flow \\
\hline & 0 & $7 \mathrm{~cm}^{3} / \mathrm{min}$ \\
Yam & 7 & 5 \\
Neem & 0 & 16 \\
Control & 0 & 0 \\
\hline
\end{tabular}


Columns with neem had similar results to the experiment without flow (Figure 4B) possibly because they have natural compounds capable of repelling juveniles and adults of $P$. coffeae to the negative direction of the column (contrary to the baits). No specimen was found in the section of $+5 \mathrm{~cm}$, reinforcing the nematicide action of neem. The highest nematode concentrations remained at positions close to the injection point, i.e., $+1 \mathrm{~cm}$
(13.5\%), $0 \mathrm{~cm}(9.8 \%)$, and $-1 \mathrm{~cm}(25.8 \%)$, and only $2.8 \%$ of the specimens moved to the last distance (approximately 34 nematodes) (Figure 4B). At five days after injection, a flow rate of $3 \mathrm{~cm}^{3} / \mathrm{min}$ was sufficient to drag the nematodes to the drainage water collected at the end of each column (Table 3). Possibly, the joint action of the neem bait and water flow provided a higher $P$. coffeae draining.

Figure 4. Distribution of Pratylenchus coffeae in soil columns filled with washed sand after water flow of $3 \mathrm{~cm}^{3} / \mathrm{min}^{2}$ with five days after nematode injection. Flow input (+), flow output (-). Column with baits of yams sectioned from the shore (A); Column with baits of leaves sectioned of neem (B); Column without bait (C). The distribution of the nematodes relative to the injection point differed between the three bait conditions by the Chi-square test at $0.01 \%$ probability.
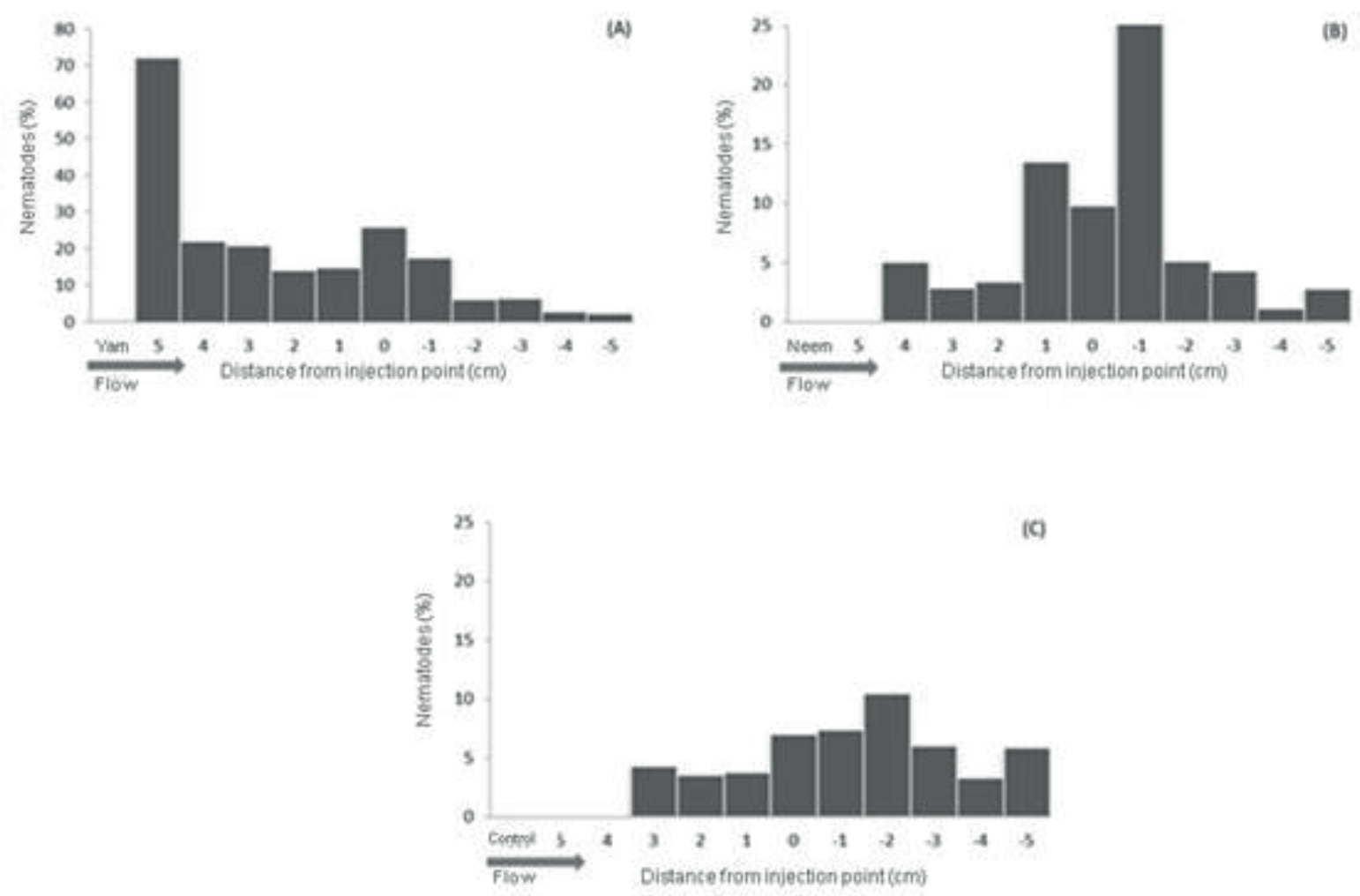

Without bait stimulus, control columns showed a nematode movement concentrated at distances near the injection point. The highest number of specimens $(10.5 \%)$ was found at position $-2 \mathrm{~cm}$, totaling 126 nematodes. Also, no nematode was observed at the distances +4 and $+5 \mathrm{~cm}$, which are near the entrance of water flow. It may be related to the strength exerted by water flow, which may have attracted the specimens to the most distant positions. Approximately 70 nematodes, or approximately $5.9 \%$, moved to the last column section $(-5 \mathrm{~cm})$, but the population remained inside the column, resisting to the water flow (Figure 4C). Fujimoto et al. (2010) verified that nematodes could move to narrower pores in the soil, making it difficult to drag them through the water flow. 
Only in the columns with neem bait nematodes were found in the drainage water, in both water flows, totalizing 7 and 16 individuals at the flow rates of 3 and $7 \mathrm{~cm}^{3} / \mathrm{min}$, respectively (Table 3 ). For the yam bait, P. coffeae was able to withstand a water flow of $3 \mathrm{~cm}^{3} / \mathrm{min}$, and only in the highest flow the nematodes were dragged (approximately 5 juveniles or adults) to water collectors at the end of each column, showing a tendency to increase dragging as the flow increased. Barros et al. (2016) observed that the increased flow rate provided a higher drag of nematodes, showing a higher number of specimens in the water collectors. Nematodes in columns without bait showed some resistance to both water flows, resulting in no nematodes found in the drainage water. The presence of nematode in the drainage water only in columns with baits may be associated with the presence of organic compounds that may affected the maintenance of nematodes in suspension. However, the absence of stimuli may have affected the activity of nematodes and, consequently, its ability to remain in suspension, hampering drag.

The flow of $7 \mathrm{~cm}^{3} / \mathrm{min}$, applied at five days after injection of $P$. coffeae, affected nematode distribution into columns with baits of sectioned yam tubers (Figure 4A), with significant differences in the frequencies (Table 2). Most of the non-leached nematodes were found near the injection point, i.e., at positions of 1 and $0 \mathrm{~cm}$, with approximate values of $10.5 \%$ (126 nematodes) and $14.8 \%$ (178 nematodes), respectively. However, a small part of the population was dragged to the column exit point, being leached in the drainage water (Table 3). Only $1.1 \%$ of the specimens were found at the distance $+5 \mathrm{~cm}$, which is the end closest to the bait (Figure $5 \mathrm{~A}$ ), although it is possible that more specimens have reached this position, being dragged due to the strength of water flow.

Figure 5. Distribution of Pratylenchus coffeae in soil columns filled with washed sand after water flow of $7 \mathrm{~cm}^{3} / \mathrm{min}^{2}$ with five days after nematode injection. Flow input (+), flow output (-). Column with baits of yams sectioned from the shore (A); Column with baits of leaves sectioned of neem (B); Column without bait (C). The distribution of the nematodes relative to the injection point differed between the three bait conditions by the Chi-square test at $0.01 \%$ probability.
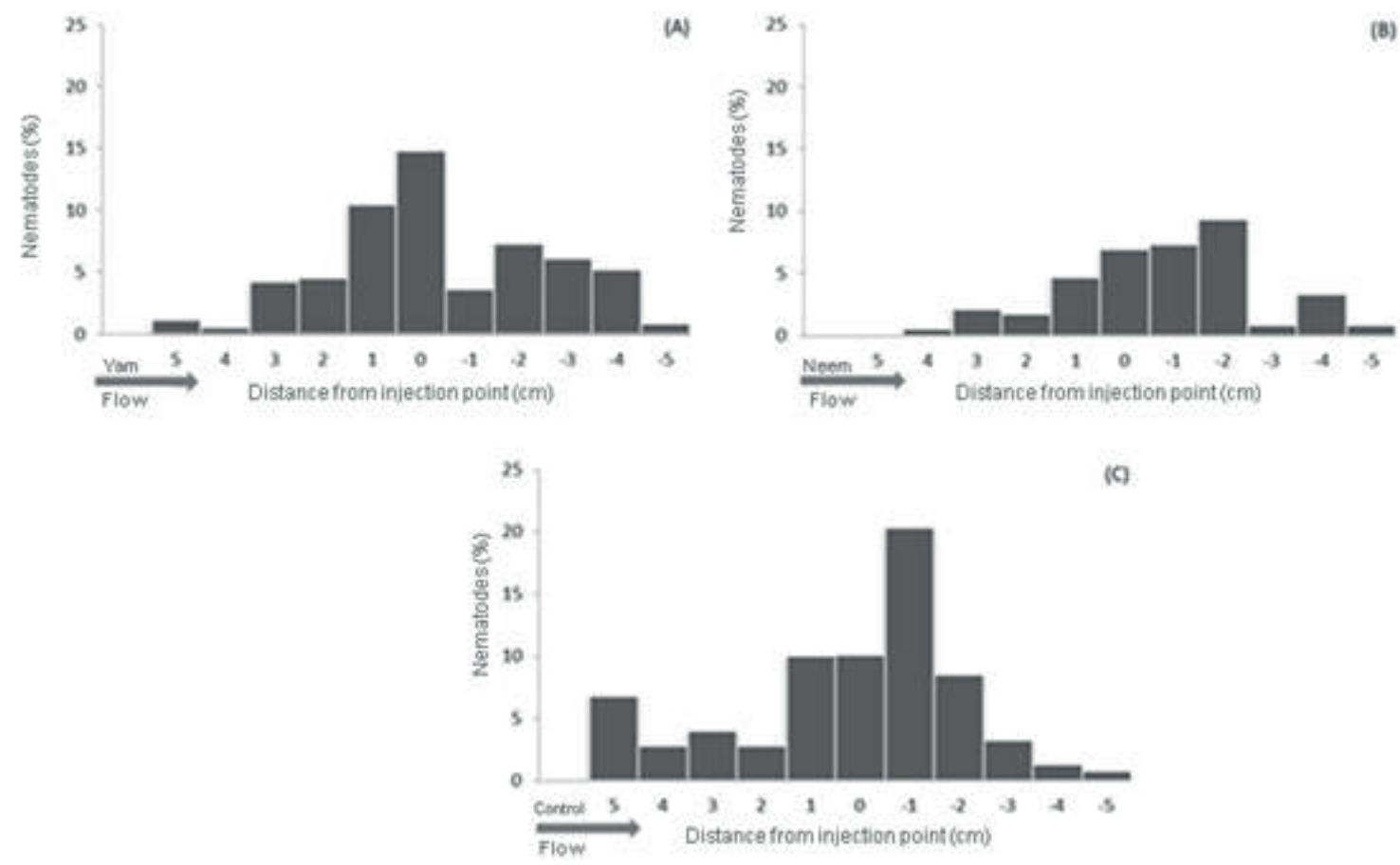
The flow rate of $7 \mathrm{~cm}^{3} / \mathrm{min}$ applied to columns with baits of neem leaves was sufficient to translocate the nematodes to distances far from the bait insertion point and, consequently, leach part of the specimens into the drainage water of the column (Table 3 ). The highest nematode concentration $(9.3 \%)$ occurred at position $-2 \mathrm{~cm}$, with 111 individuals (Figure 5B). Several studies have demonstrated the nematicide effect of neem and the efficiency in integrated plantparasitic nematode management (BARBOSA et al., 2010; CHAVES et al., 2012).

Columnswithoutbaitprovided a well-distributed movement, with the presence of nematodes in all column rings (Figure 5C). The highest $P$. coffeae concentration $(20.3 \%)$ was observed at position $-1 \mathrm{~cm}$, with 243 specimens, while and the lowest concentration $(0.75 \%)$ occurred at position -5 $\mathrm{cm}$. No specimen was dragged to the exit point of the column despite the application of water flow (Table 2).

Studies with root exudates from good host, poor host, and antagonistic plants have shown that M. incognita and M. graminicola Golden and Birchfield, 1965 present a significant migration towards good host plants when compared to nonhost plants (DUTTA et al., 2011; REYNOLDS et al., 2011), but host plant exudates may have a repellent character similar to that of antagonistic plants. Concentrated root exudates of cucumber and tomato present a repellent effect on $M$. incognita, although the diluted fractions were attractive (CASTRO et al., 1989; DIEZ; DUSENBERY, 1989). Studies that quantitatively and qualitatively characterize exudates and other plant secretions are essential in identifying which compounds and concentrations are attractive or repellent.

\section{Conclusions}

- Cut leaves of neem and sectioned yam tubers affected $P$. coffeae mobility in the absence or presence of water flows of 3 and $7 \mathrm{~cm}^{3} / \mathrm{min}$.
- The repellent action of the cut leaves of neem on $P$. coffeae occurred in the presence or absence of water flow.

- The presence of sectioned yam tubers stimulated $P$. coffeae to resist a water flow of $3 \mathrm{~cm}^{3} / \mathrm{min}$, but the stimulus was suppressed by a water flow of $7 \mathrm{~cm}^{3} /$ $\min$.

- The presence of neem leaves favored $P$. coffeae leaching at water flows of 3 and $7 \mathrm{~cm}^{3} / \mathrm{min}$.

- The absence of baits stimulated $P$. coffeae to withstand water flows of 3 and $7 \mathrm{~cm}^{3} / \mathrm{min}$.

\section{References}

ARAÚJO FILHO, J. V. de; CASTRO-MORETTI, F. R.; BONFIM JUNIOR, M. F. Pratylenchus brachyurus (Nematoda: Pratylenchidae) in Guariroba in the state of Goiás, Brazil. Helminthologia, Switzerland, v. 51, n. 4, p. 352-354, 2014. DOI: 10.2478/s11687-014-0252-5

BAERMANN, G. Eine einfache Methode zur Auffindung von Anklyostomum (Nematoden) Larven in Erdproben. Geneesk Tijdschr Nederlandsch-Indie, Batávia, v. 57, p.131-137, 1917.

BARBOSA, L. F.; AMORIM, E. P. R.; COSTA, V. K. S.; TRINDADE, R. C. P.; PEIXINHO, G. S.; CRUZ, S. J. S. Efeito de resíduos vegetais sobre Scutellonema bradys, agente causal da casca preta do inhame (Dioscorea sp.). Revista Raízes e Amidos Tropicais, Botucatu, v. 6, n. 1, p. 214-220, 2010.

BARROS, P. A.; PEDROSA, E. M. R.; SILVA, E. F. F. E.; MIRANDA, J. H.; ROLIM, M. M.; DAVID, M. F. L. Dinâmica populacional de fitonematoides sob regimes de fluxo de água em colunas de solo. Nematropica, Gainesville, v. 46, n. 2, p. 244-260, 2016.

BURR, A. H. J.; ROBINSON, A. F. Locomotion behaviour. In: GAUGLER, R.; BILGRAMI, A. L. (Ed.). Nematode behaviour. Wallingford: CAB International, 2004. p. 25-62. DOI: 10.1016/j.vetpar.2005.02.003

CASTILLO, P.; VOVLAS, N. Pratylenchus (Nematoda, Pratylenchidae): diagnosis, biology, pathogenicity and management. Leiden: Brill, 2007. 530 p. DOI: 10.1163/ ej. $9789004155640 . i-523$

CASTRO, C. E.; BELSER, N. O.; McKINNEY, H. E.; THOMASON, I. J. Quantitative bioassay for chemotaxis with plant parasitic nematodes. Journal of Chemical Ecology, New York, v. 15, n. 4, p. 1297-1309, 1989. DOI: 10.1007/BF01014831 
CHAVES, A.; PEDROSA, E. M. R.; COELHO, R. S. B.; GUIMARÃES, L. M. P.; MARANHÃO, S. R. V. L.; GAMA, M. A. S. Alternativas para o manejo integrado de fitonematoides em cana-de-açúcar. Agrária, Recife, v. 7, n. 1, p. 73-80, 2012. DOI: 10.5039/agraria.v7i1a1489

DIAS, W. P.; RIBEIRO, N. R.; PIVATO, A.; MOLINA, D. Avaliação da reação de genótipos de soja ao nematoide das lesões radiculares (Pratylenchus brachyurus). In: REUNIÃO DE PESQUISA DE SOJA DA REGIÃO CENTRAL DO BRASIL, 30., 2008, Rio Verde. Resumos... Rio Verde: Comigo e EMBRAPA Soja, 2008. p. 137-139.

DIEZ, J. A.; DUSENBERY, D. B. Repellent of rootknot nematodes from exudate of host roots. Journal of Chemical Ecology, New York, v. 15, n. 10, p. 2445-2455, 1989. DOI: $10.1007 / \mathrm{BF} 01020375$

DU CHARME, E. P. Sub-soil drainage as a factor in the spread of the burrowing nematode. In: ANNUAL MEETING OF THE FLORIDA STATE HORTICULTURAL SOCIETY, 68., 1955, Flórida. Proceedings of the Florida State Horticultural Society. Flórida: Florida State Horticultural Society, 1955. p. 2931.

DUTTA, T. K.; POWERS, S. J.; KERRY, B. R.; GAUR, H. S.; CURTIS, R. H. C. Comparison of host recognition, invasion, development and reproduction of Meloidogyne graminicola and $M$. incognita on rice and tomato. Nematology, Leiden, v. 13, n. 5, p. 509-520, 2011. DOI: $10.1163 / 138855410 \times 528262$

EGUNJOBI, O. A.; AFOLAMI, S. O. Effects of neem (Azadirachta indica) leaf extracts on population of Pratylenchus brachyurus and on the growth and yield of mayze. Nematologica, Leiden, v. 22, n. 2, p. 125-132, 1976. DOI: 10.1163/187529276X00193

EMPRESA BRASILEIRA DE PESQUISA AGROPECUÁRIA - EMBRAPA. Manual de métodos de análise de solo. 2. ed. rev. atual. - Rio de Janeiro: EMBRAPA, 2011. 306 p.

FERRAZ, L. C. C. B.; BROWN, D. J. F. Nematologia de plantas: fundamentos e importância. Manaus: Norma Editora, 2016. v. 1, 251 p.

FERRAZ, S.; FREITAS, L. G.; LOPES, E. A.; DIASARIEIRA, C. R. Manejo sustentável de fitonematoides. Viçosa, MG: UFG, 2010. 306 p.

FERRAZ, S.; FREITAS, L. G. Use of antagonistic plants and natural products. In: CHEN, Z.X.; CHEN, S.Y.; DICKSON, D.W. (Ed.). Nematology: advances and perspectives. Wallingford UK: CABI Publishing, 2004. p. 931-977. DOI: $10.1017 / \mathrm{S} 0031182005218589$

FRANCILINO, A. H.; PEDROSA, E. M. R.; SILVA,
E. F. F. E.; ROLIM, M. M.; CARDOSO, M. S. O.; MARANHAO, S. R. V. L. Efeito do fluxo de água, isca vegetal e volume de poros do solo na mobilidade de Pratylenchus coffeae. Nematropica, Gainesville, v. 47, n. 1, p. 63-73, 2017.

FUJimOTO, T.; HASEGAWA, S.; OTOBE, K.; MIZUKUBO, T. Effect of water flow on the mobility of the root-knot nematode Meloidogyne incognita in columns filled with glass beads, sand or andisol. Applied Soil Ecology, Amsterdam, v. 43, n. 2, p. 200-205, 2009. DOI: 10.1016/j.apsoil.2009.07.006

FUJIMOTO, T.; HASEGAWA, S.; OTOBE, K.; MIZUKUBO, T. The effect of soil water flow and soil properties on the motility of second-stage juveniles of the root-knot nematode (Meloidogyne incognita). Soil Biology \& Biochemistry, Oxford, v. 42, n. 7, p. 10651072, 2010. DOI: 10.1016/j.apsoil.2009.07.006

GOULART, A. M. C. Aspectos gerais sobre nematoides das lesões radiculares (gênero Pratylenchus). Planaltina: Documentos, EMBRAPA Cerrados, 2008. 30 p.

GRIFFITHS, B. S.; CAUL, S. Migration of bacterialfeeding nematodes, but not protozoa, to decomposing grass residues. Biology and Fertility of Soils, New York, v. 15 , n. 3 , p. 201-207, 1993. DOI: 10.1007/BF00361612

HOLBEIN, J.; GRUNDLER, F. M. W.; SIDDIQUE, S. Plant basal resistance to nematodes: an update. Journal of Experimental Botany, Oxford, v. 67, n. 7, p. 20492061, 2016. DOI:10.1093/jxb/erw005.

HOSSAIN, M. A.; AL-TOUBI, W. A. S.; WELI, A. M.; AL-RIYAMI, Q. A.; AL-SABAHI, J. N. Identification and characterization of chemical compounds in different crude extracts from leaves of omani neem. Journal of Taibah University forScience, Medina, v. 7, n. 4, p. 181188, 2013. DOI: 10.1016/j.jtusci.2013.05.003

MAJD TAHERI, Z. M.; MAAFI, Z. T.; SUBBOTIN, S.; POURJAM, E.; ESKANDARI, A. Molecular and phylogenetic studies on Pratylenchidae from Iran with additional data on Pratylenchus delattrei, Pratylenchoides alkani and two unknown species of Hirschmanniella and Pratylenchus. Nematology, Leiden, v. 15, n. 6, p. 633651, 2013. DOI: 10.1163/15685411-00002707

MOURA, R. M. Problemas fitossanitários do inhame no Nordeste e proposta para um sistema integrado de controle. In: SIMPÓSIO NACIONAL SOBRE AS CULTURAS DO INHAME E DO TARO, 2., 2002, João Pessoa. Anais... João Pessoa: EMEPA, 2002. p. 68-72.

MOURA, R. M.; MONTEIRO, A. Pratylenchus coffeae on yam in Brazil. Fitopatologia Brasileira, Brasília, v. 20, n. 6, p. 256, 1995. DOI: 10.1590/S010041582002000600019 
NEVES, B. P.; OLIVEIRA, I. P.; NOGUEIRA, J. C. M. Cultivo e utilização do nim indiano. Goiânia: EMBRAPA, 2003. 32 p.

OKA, Y. Mechanisms of nematode suppression by organic soil amendments: a review. Applied Soil Ecology, Amsterdam, v. 44, n. 2, p. 101-115, 2010. DOI: 10.1016/j. apsoil.2009.11.003

PINHEIRO, J. B. Nematoides em hortaliças formadoras de raízes e tubérculos: ocorrência, manejo e desafios. In: CONGRESSO BRASILEIRO DE NEMATOLOGIA, 33 ., 2016, Petrolina. Anais ... Piracicaba: Sociedade Brasileira de Entomologia, 2016 Disponível em: http://ainfo.cnptia. embrapa.br/digital/bitstream/ item/146356/1/palestra-6JBPinheiro.pdf. Acesso em: 25 jun. 2019.

REYNOLDS, A. M.; DUTTA, T. K.; CURTIS, R. H. C.; POWERS, S. J.; GAUR, H. S.; KERRY, B. R. Chemotaxis can take plant-parasitic nematodes to the source of a chemo-attractant via the shortest possible routes. Journal of the Royal Society Interface, Great Britain, v. 8, n. 57, p. $568-577,2011$. DOI: $10.1098 /$ rsif.2010.0417
SCHUMUTTERER, H. Properties and potential of natural pesticides from the neem tree, Azadirachta indica. Annual Review Entomology, Maryland, v. 35, n. 1, p. 271-298, 1990. DOI: 10.1146/annurev.ento.35.1.271

SIDDIQUI, M. A.; ALAM, M. M. Effect of root-exudates of neem and Persian lilac on plant parasitic nematodes. Anzeirger Schaedlingskd. Pflanzenschutz Umweltschutz, Switzerland, v. 62, n. 2, p. 33-35, 1989. DOI: $10.1007 /$ BF01905964

TALWANA, H.; SIBANDA, Z.; WANJOHI, W.; KIMENJU, W.; LUAMBANO-NYONI, N.; MASSAWE, C.; MANZANILLA-LÓPEZ, R. H.; DAVIES, K. G.; HUNT, D. J.; SIKORA, R. A.; COYNE, D. L.; GOWENL, S. R.; KERRY, B. R. Agri-cultural nematology in East and Southern Africa: problems, management strategies and stakeholder linkages. Pest Management Science, Great Britain, v. 72, n. 2, p. 226-245, 2016. DOI: 10.1002/ ps. 4104

WILLIAMSON, V. M.; KUMAR, A. Nematode resistance in plants: the battle underground. Trends in Genetics, Amsterdam, v. 22, n. 7, p. 396-403, 2006. DOI: 10.1016/j.tig.2006.05.003 